\title{
A multilevel analysis of determinants of PMTCT service utilisation among women during the antepartum, intrapartum and postpartum period in Ethiopia
}

Tsegaye Gebremedhin ${ }^{1}$, Tesfa Sewunet Alamneh², Asebe Hagos ${ }^{1}$, Beimnet Desalegn ${ }^{3}$ and Nigusu Worku*

\begin{abstract}
Background: Mother-to-child transmission (MTCT) is the largest source of HIV infection in children below the age of 15 years, and more than $90 \%$ of pediatric HIV are infected through mother to child transmission. Without treatment, one-half of those infected children will die before the age of 2 years. Despite this, there is limited evidence on PMTCT and its determinants. Therefore, this study aimed to determine the factors affecting the PMTCT service utilisation in Ethiopia.

Methods: A two-stage stratified sampling technique was used to identify 4081 women from 2016 Ethiopian Demographic and Health Survey (EDHS). A multilevel mixed-effect binary logistic regression analysis was used to identify the individual and community level factors associated with PMTCT services utilisation. In the final model, a $p$-value of $<0.05$ and Adjusted Odds Ratio (AOR) with 95\% confidence interval (Cl) were used to declare statistically significant factors with the utilisation.

Results: Overall, 21.9\% (95\% Cl, 20.6-23.2) of the women were utilized PMTCT services. Educational status; primary (AOR: 1.65, 95\% Cl: 1.27-2.13), secondary (AOR: 1.52, 95\% Cl: 1.03-2.24) and higher school (AOR: 2.48, 95\% Cl: 1.45-4.22), poorer (AOR: 1.62, 95\% Cl: 1.12-2.37), middle (AOR: 1.82, 95\% Cl: 1.10-3.02), richer (AOR: $2.44,95 \%$ Cl: $1.42-4.21$ ) and richest (AOR: $4.45,95 \%$ Cl: 2.43-8.14) wealth status and orthodox religion follower (AOR: 1.62, 95\% Cl: 1.22-2.16) were the individual level factors. Moreover, having basic (AOR: 1.66, 95\% Cl: 1.34-2.06) and comprehensive (AOR: 1.73, 95\% Cl: 1.38-2.18) knowledge on HIV prevention methods, having knowledge on MTCT of HIV (AOR: 2.69, 95\% Cl: 2.16-3.36) were also factors at individual level. Whereas, rural residence (AOR: 0.52 , 95\% Cl: 0.32-0.85) was the community level factors that affects the utilization.

Conclusions: Less than one-fourth of the mothers had utilised the PMTCT services in Ethiopia. To increase the utilisation of the services, the health care providers should give emphases on counselling, awareness creation, and strengthen the existing frontline integrated health care services in the country.
\end{abstract}

Keywords: PMTCT, Utilization, Multilevel, Ethiopia

\footnotetext{
* Correspondence: nigusuworku29@gmail.com

'Department of Health Systems and Policy, Institute of Public Health, College of Medicine and Health Sciences, University of Gondar, Gondar, Ethiopia

Full list of author information is available at the end of the article
}

(c) The Author(s). 2021 Open Access This article is licensed under a Creative Commons Attribution 4.0 International License, which permits use, sharing, adaptation, distribution and reproduction in any medium or format, as long as you give appropriate credit to the original author(s) and the source, provide a link to the Creative Commons licence, and indicate if changes were made. The images or other third party material in this article are included in the article's Creative Commons licence, unless indicated otherwise in a credit line to the material. If material is not included in the article's Creative Commons licence and your intended use is not permitted by statutory regulation or exceeds the permitted use, you will need to obtain permission directly from the copyright holder. To view a copy of this licence, visit http://creativecommons.org/licenses/by/4.0/. The Creative Commons Public Domain Dedication waiver (http://creativecommons.org/publicdomain/zero/1.0/) applies to the data made available in this article, unless otherwise stated in a credit line to the data. 


\section{Background}

Globally, an estimated 1.8 million children were living with the human immune deficiency virus (HIV), and about 110,000 children died from AIDS-related illness in 2015. More than 1.6 million children were living with HIV in Sub-Saharan Africa [1]. In Ethiopia, there were 62,000 children less than 15 years old living with HIV, 3800 new infections, and 2900 AIDS-related deaths among children in 2016 [2].

Mother-to-child transmission (MTCT) is the largest source of HIV infection in children below the age of 15 years [3], and more than $90 \%$ of pediatric HIV are infected through mother-to-child transmission [4]. Without treatment, one-half of the infected children will die before 2 years [5]. In the absence of any intervention, MTCT rates range from 15 to $45 \%$ [6]. The vast majority of these infections were averted between 2010 and 2015, globally, because of PMTCT service and ART initiation [7].

In August 2012, Ethiopia adopted the World Health Organization (WHO) PMTCT programmatic shift services strategy [8]. PMTCT option $\mathrm{B}+$ has the greatest benefits in settings with high prevalence and high fertility in which initiating ART among all pregnant and breastfeeding women would reduce HIV incidence and prevalence of transmission in both current and future pregnancies [9]. The percentage of pregnant women living with HIV who were receiving antiretroviral therapy (ART) increases from $64 \%$ in 2013 to $73 \%$ in 2014 and reducing the incidence of new child HIV infections by $65 \%$ since 2009 in Ethiopia [10]. However, only 35\% of HIV infected children received ART therapy in Ethiopia [2]. A meta-analysis finding showed that the pooled prevalence of MTCT of HIV in Ethiopia was 9.93\%, which means almost one in every ten HIV-exposed infants become HIV positive. Mothers who did not use the recommended PMTCT intervention during pregnancy, labor and delivery, and breastfeeding are more than seven times more likely to transmit HIV to their child [11]. The PMTCT service utilisation in Afar, Ethiopia, was reported as $67.7 \%$ [12]. Only 18 and 9\% of respondents attended the facility for HIV counselling and testing (HCT) and receiving antiretroviral prophylaxis, respectively, in Addis Ababa, Ethiopia [13]. Another study in the Amhara region of Ethiopia reported that the utilisation of PMTCT service among pregnant women attending ANC was $61.3 \%$. The utilisation of PMTCT service among ANC attendants in rural areas was $57.8 \%$. More than half $(55.5 \%)$ of the pregnant mothers did not start ANC properly [14].

Different literatures revealed that PMTCT service utilisation was affected by knowledge of PMTCT, residence, internal referral system, health professional-client interaction, fear, and waiting time, the number of ANC visits, education status, and involvement in PMTCT services.
PMTCT training, lack of materials and equipment for PMTCT service, language barrier, and the low number of PMTCT providers were the major barriers identified by the PMTCT service provider in providing PMTCT service $[12,14]$.

Empirical studies have been conducted on PMTCT services utilisation and associated factors, but to our knowledge, there is no study conducted at the national level, which identifies the individual and community level determinants of PMTCT services utilisation. Thus, this study aimed to determine the individual and community level factors of PMTCT services utilisation among women during antepartum, intrapartum, and postpartum periods in Ethiopia from the 2016 Ethiopian demographic and health survey. This study may provide additional information by identifying the individual and community level factors that improve the PMTCT service.

\section{Methods}

\section{Study settings and data source}

The study was carried out in Ethiopia, which is the second populous country in Africa, with a population density of 115 people per $\mathrm{Km}^{2}$ [15]. Ethiopia is divided into two administrative units (Addis Ababa and Dire Dawa) and nine regions (Tigray, Afar, Amhara, Oromia, Somali, Benishangul, SNNPR, Gambella, and Harari).

This analysis used the 2016 Ethiopian Demographic and Health Survey (EDHS) data, which is a nationally representative household survey data conducted every 5 years by Ethiopia's Central Statistical Agency (CSA) [16].

\section{Sampling procedures and sample size}

In the survey, all women aged 15 to 49 who are regular members of the selected households were included. Finally, data from the 2016 EDHS datasets were analysed using STATA version 14 software, and a total weighted of 4081 women were included in the final analysis. Individual and community level independent variables were identified and further analysis was done.

\section{Measurements of variables}

The study's dependent variable was PMTCT utilization. PMTCT utilization was measured as a dichotomous variable; when a pregnant woman received all the components of PMTCT services (pre and post-test counselling, HIV testing, and receiving test results) during each of the three phases of the visit (antepartum, intrapartum, and postpartum), the utilisation was measured as 'YES', otherwise 'NO' $[4,6,9,17]$. The information was gathered from mother's verbal responses; during ANC visits, labor and delivery, and postnatal care.

Explanatory variables included the individual and community levels variable. Both maternal (socio-demographic and maternal health-care-related characteristics) 
and child-related variables were included in the individual level variables. At the same time, community-level variables included place of residence, region, distance to a health facility, community-level poverty, women empowerment and media exposure.

Distance to a health facility was assessed by the question "distance to the nearest health facility is a problem?" and the responses were categorised as "big problem" or "not a problem".

Women empowerment was measured by their decisionmaking power and the justification for wife-beating. Women who were empowered were those who, in all situations, engaged in decision-making, either alone or with their husbands, and never justified wife-beating.

The asset index was used to assess community-level poverty, based on data from the entire sample on separate scores prepared for rural and urban households, and combined to produce a single asset index for all households at the community level, which was then ranked into three categories (poor, middle, and rich).

Community media exposure was assessed as "yes" if they have access to all three media (newsletter, radio, and TV) at least once a week, otherwise "no".

\section{Data processing and statistical analysis}

The data were extracted, cleaned, re-coded, and analysed using STATA version 14.1 software. Weighting was considered during the analysis to adjust for unequal probability of selection due to the sampling design used in EDHS data.

Since the DHS data had hierarchical nature (an individual were nested within communities), a two-level binary logistic regression model was fitted to estimate the effect of both individual and community-level variables on PMTCT service utilisation [18]. As a principle in multilevel analysis, four models were considered for the data. The first model was an empty (null) model without any explanatory variables. The second model was fitted with individual-level variables only; the third model was fitted community-level variables only and the fourth was adjusted for both individual and community-level variables. The variation between clusters was assessed by computing Intra-Class Correlation Coefficient (ICC) and Proportional Change in Variance (PCV). The ICC is the proportion of variance explained by the grouping structure in the population which computed as: ICC $=\frac{\sigma_{\mu}{ }^{2}}{\sigma_{\mu}{ }^{2}+\pi^{2} / 3}$; where the standard logit distribution has a variance of $\pi^{2} / 3, \sigma_{\mu}^{2}$ indicates the community variance. Whereas PCV measures the total variation explained by individual and community level variables in the models as compared to the null model, which is computed as: variance of null model-variance of full model $[19,20]$. Both bi-variable and multivariable multilevel binary logistic regressions were estimated and a $p$-value of less than 0.05 and an Adjusted Odds Ratio (AOR) with 95\% Confidence Interval (CI) were used to declare statistically significant factors associated with PMTCT services utilisation in the selected model.

\section{Results \\ Socio-demographic and economic characteristics of participants}

A total of 4081 women were included in the final analysis. The women's mean age was $28.0 \pm 6.4$ years, and $79.6 \%$ of the women were rural dwellers. The majority (35.1\%) of the households were in the poorest wealth status, and the mean family size was $5.8 \pm 2.3$. Nearly 15.2 and $5.0 \%$ of the participants were from the Oromia region and Addis Ababa city, respectively. Half of the participants were Muslim in religion. Of the participants, 95.1\% were married, $59.2 \%$ with no education, and $61.5 \%$ had no work. Similarly, 45.3 and $9.9 \%$ of their husbands/partners had no education and work, respectively (Table 1).

\section{Obstetric history of participants}

The majority $(53.7 \%)$ of the women were multipara, and $55.6 \%$ were in the age group of 18 to 24 years when they gave their first birth. Two-thirds of the women were received ANC visits for their recent pregnancy. Of those who had ANC visits, 55.0\% had four and above times, and $52.8 \%$ were done their first antenatal care visits between the fourth and sixth months of their gestational age. Furthermore, $41.0 \%$ of the women delivered at health facilities, and $8.9 \%$ of them had postnatal checks within 2 months after delivery, in which nearly $41 \%$ of the postnatal checks' services were provided by nurses (Table 2).

\section{Health services related factors, women empowerments, and community-level factors}

Of the total participants, only $5.9 \%$ were had access to all media types (radio, newsletter, and television) more than once a week. Nearly $46 \%$ of the participants responded that the health facilities are not far. One-third of the women were empowered, and $54.8 \%$ of the community were in poor wealth status (Table 3).

\section{Knowledge about HIV and MTCT of HIV}

Of the total respondents, $38.2 \%$ had the basic knowledge of HIV prevention methods, and only $22.4 \%$ of the women had a comprehensive knowledge of HIV. Furthermore, $52.2 \%$ of the women knew that HIV could be transmitted during pregnancy, labor and delivery, and breastfeeding. 
Table 1 Socio-demographic and economic characteristics of study participants in Ethiopia, $2016(n=4081)$

\begin{tabular}{|c|c|c|c|}
\hline Variables & Category & $\begin{array}{l}\text { Frequency } \\
\text { (n) }\end{array}$ & $\begin{array}{l}\text { Percent } \\
\text { (\%) }\end{array}$ \\
\hline \multirow[t]{3}{*}{ Age in complete years } & $15-24$ & 1279 & 31.3 \\
\hline & $25-34$ & 2035 & 49.9 \\
\hline & $>=35$ & 767 & 18.8 \\
\hline \multirow[t]{2}{*}{ Residence } & Urban & 832 & 20.4 \\
\hline & Rural & 3249 & 79.6 \\
\hline \multirow[t]{11}{*}{ Region } & Tigray & 443 & 10.8 \\
\hline & Afar & 383 & 9.4 \\
\hline & Amhara & 374 & 9.2 \\
\hline & Oromia & 619 & 15.2 \\
\hline & Somali & 527 & 12.9 \\
\hline & Benishangul & 323 & 7.9 \\
\hline & SNNPR & 489 & 12.0 \\
\hline & Gambela & 268 & 6.6 \\
\hline & Harari & 234 & 5.8 \\
\hline & Addis Ababa & 207 & 5.0 \\
\hline & Dire Dawa & 214 & 5.2 \\
\hline \multirow[t]{4}{*}{ Religion } & Muslim & 2041 & 50.0 \\
\hline & Orthodox & 1226 & 30.0 \\
\hline & Protestant & 715 & 17.5 \\
\hline & Others $^{a}$ & 99 & 2.5 \\
\hline \multirow[t]{2}{*}{ Sex of head of household } & Male & 3224 & 79.0 \\
\hline & Female & 857 & 21.0 \\
\hline \multirow[t]{5}{*}{ Household wealth status } & Poorest & 1432 & 35.1 \\
\hline & Poorer & 683 & 16.7 \\
\hline & Middle & 567 & 13.9 \\
\hline & Richer & 512 & 12.6 \\
\hline & Richest & 887 & 21.7 \\
\hline \multirow[t]{2}{*}{ Current marital status } & Married & 3882 & 95.1 \\
\hline & Unmarried & 199 & 4.9 \\
\hline \multirow[t]{4}{*}{ Educational status of women } & No education & 2417 & 59.2 \\
\hline & $\begin{array}{l}\text { Primary } \\
\text { education }\end{array}$ & 1138 & 27.9 \\
\hline & $\begin{array}{l}\text { Secondary } \\
\text { education }\end{array}$ & 347 & 8.5 \\
\hline & Higher & 179 & 4.4 \\
\hline \multirow{5}{*}{$\begin{array}{l}\text { Educational status of } \\
\text { husband's/partner's } \\
\text { ( } n=3882)\end{array}$} & No education & 1759 & 45.3 \\
\hline & $\begin{array}{l}\text { Primary } \\
\text { education }\end{array}$ & 1302 & 33.5 \\
\hline & $\begin{array}{l}\text { Secondary } \\
\text { education }\end{array}$ & 449 & 11.6 \\
\hline & $\begin{array}{l}\text { Higher } \\
\text { education }\end{array}$ & 341 & 8.8 \\
\hline & Don't know & 31 & 0.8 \\
\hline Respondent's occupation & No work & 2510 & 61.5 \\
\hline
\end{tabular}

Table 1 Socio-demographic and economic characteristics of study participants in Ethiopia, $2016(n=4081)$ (Continued)

\begin{tabular}{llll}
\hline Variables & Category & $\begin{array}{l}\text { Frequency } \\
(\mathbf{n})\end{array}$ & $\begin{array}{l}\text { Percent } \\
(\%)\end{array}$ \\
\hline & Professional & 508 & 12.5 \\
& Agricultural & 736 & 18.0 \\
& Daily labour & 214 & 5.2 \\
& Others & & \\
& No work & 385 & 9.8 \\
Husband's/partner's & Professional & 648 & 16.7 \\
occupation (n=3882) & Agricultural & 2044 & 52.7 \\
& Daily labour & 418 & 10.8 \\
& Others & 387 & 9.9
\end{tabular}

others: catholic, traditional, Job ${ }^{\mathrm{b}}$ merchant, self-employed

\section{PMTCT services utilisation}

Overall, 21.9\% (95\% CI: 20.6-23.2) of the women were received all the components of PMTCT services during the antepartum and intrapartum periods. Only $25.2 \%$ of the women have received all the counselling components on HIV (the counselling contains; babies getting HIV from their mother, preventing the virus, and being tested for HIV). Moreover, $26.2 \%$ of the women were tested for HIV tests, received their HIV test results, and received post-test counselling.

\section{Random effects (measures of variation)}

There was a significant variation in the utilisation of PMTCT services among women across the clusters. The ICC in the null model for PMTCT services utilisation was $48.67 \%$. In other words, $48.67 \%$ of the variation in PMTCT services utilisation among women was due to the differences between clusters (between-cluster variation). Also, the median odds ratio also revealed that PMTCT services utilisation was heterogeneous among clusters. It was 5.34 in the first model, which implies that women within cluster of higher PMTCT services utilisation had 5.34 times higher chance of PMTCT services utilisation than women within cluster of lower PMTCT services utilisation if women were selected randomly from two different clusters (EAs). Regarding PCV, about $73.00 \%$ of PMTCT services utilisation variability was explained by the full model. The full model was selected as the best-fitted model (had the lowest information criterion) (Tables 4 and 5).

\section{Factors affecting PMTCT services service utilisation (fixed effects)}

After adjusting for individual and community level factors (model 3), women's educational status, wealth status, religion, knowledge on HIV prevention methods, comprehensive knowledge on HIV, knowledge on 
Table 2 Obstetric characteristics of study participants in Ethiopia, $2016(n=4081)$

\begin{tabular}{|c|c|c|c|}
\hline Variables & Category & Frequency (n) & Percent (\%) \\
\hline \multirow[t]{3}{*}{ Age of the mother at first birth (in years) } & $<18$ & 1450 & 35.5 \\
\hline & $18-24$ & 2270 & 55.6 \\
\hline & $25+$ & 361 & 8.9 \\
\hline \multirow[t]{3}{*}{ Parity } & Primipara & 881 & 21.6 \\
\hline & Multipara & 2192 & 53.7 \\
\hline & Grand multipara & 1008 & 24.7 \\
\hline \multirow[t]{2}{*}{ ANC visit } & No & 1327 & 32.5 \\
\hline & Yes & 2754 & 67.5 \\
\hline \multirow[t]{2}{*}{ ANC visit $(n=2754)$} & Once & 1239 & 45.0 \\
\hline & Four and above & 1515 & 55.0 \\
\hline \multirow[t]{3}{*}{ Timing of 1st ANC check in months $(n=2754)$} & $1-3$ & 1032 & 37.5 \\
\hline & $4-6$ & 1455 & 52.8 \\
\hline & $7+$ & 267 & 9.7 \\
\hline \multirow[t]{3}{*}{ Wanted pregnancy when became pregnant } & Then & 3312 & 81.2 \\
\hline & Later & 545 & 13.3 \\
\hline & No more & 224 & 5.5 \\
\hline \multirow[t]{3}{*}{ The desire for more children } & Wants & 2803 & 68.7 \\
\hline & Undecided & 207 & 5.1 \\
\hline & Wants no more & 1071 & 26.2 \\
\hline \multirow[t]{2}{*}{ Place of delivery } & Home & 2409 & 59.0 \\
\hline & Health facility & 1672 & 41.0 \\
\hline \multirow[t]{2}{*}{ PNC check within 2 months } & Yes & 362 & 8.9 \\
\hline & No & 3719 & 91.1 \\
\hline \multirow[t]{5}{*}{ The person who provided PNC services $(n=362)$} & Doctor & 56 & 15.5 \\
\hline & Nurse & 148 & 40.9 \\
\hline & Midwife & 31 & 8.6 \\
\hline & HEWs & 110 & 30.4 \\
\hline & Others & 17 & 4.7 \\
\hline \multirow[t]{3}{*}{ Timing after delivery postnatal check took place $(n=362)$} & Within $24 \mathrm{~h}$ & 39 & 10.8 \\
\hline & 1-7th day & 197 & 54.4 \\
\hline & After the 7th day & 126 & 34.8 \\
\hline \multirow[t]{2}{*}{ Currently pregnant } & Yes & 220 & 8.4 \\
\hline & No & 3861 & 94.6 \\
\hline \multirow[t]{3}{*}{ Current pregnancy wanted $(n=220)$} & Then & 169 & 76.8 \\
\hline & Latter & 37 & 16.8 \\
\hline & Not at all & 14 & 6.4 \\
\hline
\end{tabular}

ANC Antenatal care, PNC Postnatal care

MTCT, and residence were significantly associated with the utilisation of PMTCT services among women.

Accordingly, the odds of PMTCT utilisation among women who completed primary, secondary, and higher school were 1.65 (AOR: 1.65, 95\% CI: 1.27-2.13), 1.52 (AOR: 1.52, 95\% CI: 1.03-2.24), and 2.48 (AOR: 2.48, 95\% CI: 1.45-4.22) times higher than those who did not have education, respectively. Women who are in the poorer, middle, richer, richest wealth status were had 1.62 (AOR: 1.62, 95\% CI: 1.12-2.37), 1.82 (AOR: 1.82, 95\% CI: 1.10-3.02), 2.44 (AOR: 2.44, 95\% CI: 1.42-4.21), and 4.45 (AOR: 4.45, 95\% CI: 2.43-8.14) times higher odds of PMTCT services utilisation compared to those who are in the poorest wealth status, respectively. 
Table 3 Health services related, community women empowerments and other community-level chrematistics of study participants in Ethiopia, $2016(n=4081)$

\begin{tabular}{|c|c|c|c|}
\hline Variables & Category & Frequency (n) & Percent (\%) \\
\hline \multirow[t]{2}{*}{ Exposure to mass media } & No & 3840 & 94.1 \\
\hline & Yes & 241 & 5.9 \\
\hline \multirow[t]{2}{*}{ Distance to the health facility } & Big problem & 2207 & 54.1 \\
\hline & Not a problem & 1874 & 45.9 \\
\hline \multirow[t]{2}{*}{ Women empowerment $(n=3882)$} & Not empowered & 2626 & 67.6 \\
\hline & Empowered & 1256 & 32.4 \\
\hline \multirow[t]{3}{*}{ Community-level poverty } & Poor & 2235 & 54.8 \\
\hline & Middle & 692 & 16.9 \\
\hline & Rich & 1154 & 28.3 \\
\hline
\end{tabular}

Besides, those orthodox religion follower women were 1.62 times more utilise services compared to those who follow Muslim religion (AOR: 1.62, 95\% CI: 1.22-2.16). Those women who had the basic knowledge of HIV prevention methods were 1.66 times more utilise the services compared to their counterparts (AOR: 1.66, 95\% CI: 1.34-2.06) and women who had a comprehensive knowledge of HIV were utilised the services PMTCT services 1.73 times more than their counterparts (AOR: 1.73, 95\% CI: 1.38-2.18). Women who had knowledge on MTCT of HIV were 2.69 times more utilised the PMTCT services than those who did not have knowledge (AOR:2.69, 95\% CI:2.16-3.36). Furthermore, those rural dwellers were $48 \%$ less likely to utilise the PMTCT services compared to those urban dwellers (AOR: 0.52, 95\% CI: 0.32-0.85) (Table 5).

\section{Discussion}

The study identified the individual and community level determinants of PMTCT services utilisation in Ethiopia. Overall, $21.9 \%$ (95\% CI: 20.6-23.2) of the women were utilised the PMTCT services during the antepartum, intrapartum, and postpartum periods. Women's educational status, wealth status, religion, knowledge on HIV prevention methods, comprehensive knowledge on HIV, knowledge on MTCT, and residence were the determinants of PMTCT services utilisation.

The finding is in line with that of a study conducted in Addis Ababa, in which 18\% of women utilised PMTCT services [21]. However, this result was greater than the finding of EDHS 2011 [22]. This higher finding might be because of the mother's awareness, access to health services, health service expansion, and increased number of health professions, but lower than these of studies conducted in East Hararge Zone (72.8\%) [23], Hawassa city (90.3\%) [24], Afar region (67.7\%) [25], Enugu, southeast Nigeria (93.4\%), and Uganda (30.1\%) [26], The variation might be our study was a national aggregated data.

This study's findings show that women who were completed primary, secondary, and higher education levels were $(1.65,1.52$, and 2.84) times more likely to utilise PMTCT services than those who were illiterates. This finding was supported by a study done in the Afar region [25], which revealed that being uneducated was one of the barriers to PMTCT services utilisation. This might be due to the education opportunity, contributes to PMTCT services knowledge, and also study from Kombolcha Town, South Wollo [27] shows a strong association between knowledge of PMTCT service utilisation and educational status. The possible reason might

Table 4 Result from a random intercept model (a measure of variation) for PMTCT services utilisation among pregnant and labouring women at cluster level by multilevel logistic regression analysis, EDHS 2016

\begin{tabular}{llll}
\hline Measure of vibrations & Model 0 (null model) & Model 1 & Model 2 \\
\hline Variance & 3.11 & 0.86 & 1.31 \\
Explained variation (PCV) (\%) & Ref. & 72.35 & 57.87 \\
ICC (\%) & 48.67 & 20.72 & 28.5 \\
MOR & 5.34 & 2.41 & 2.97 \\
Model fitness & & & 2.39 \\
Deviance (-2* log-likelihood) & 3742.72 & 3122.64 & 3207.70 \\
AIC & 3746.71 & 3176.65 & 3223.70 \\
\hline AIC Akaike's Information Criterion, ICC Intra-class Correlation Coefficient, PCV Proportional Change in Variance, Model 0: without independent variables (null
\end{tabular}
model), Model 1: only individual-level variables, Model 2: only community-level variables, Model 3: individual and community-level variables (full model). 
Table 5 Multilevel logistic regression analysis of individual and community-level factors associated with PMTCT option B+ services utilization among women in Ethiopia, EDHS 2016

\begin{tabular}{|c|c|c|c|c|c|c|}
\hline \multirow[t]{2}{*}{ Variables } & \multicolumn{2}{|c|}{ РMTCT option B+ } & \multirow[t]{2}{*}{ COR $(95 \% \mathrm{Cl})$} & \multirow{2}{*}{$\begin{array}{l}\text { Model } 1 \\
\text { AOR }(95 \% \mathrm{Cl})\end{array}$} & \multirow{2}{*}{$\begin{array}{l}\text { Model } 2 \\
\text { AOR }(95 \% \mathrm{Cl})\end{array}$} & \multirow{2}{*}{$\begin{array}{l}\text { Model } 3 \\
\text { (AOR }(95 \% \mathrm{Cl})\end{array}$} \\
\hline & $\begin{array}{l}\text { Utilized } \\
\text { n (\%) }\end{array}$ & $\begin{array}{l}\text { Not utilized } \\
\mathrm{n}(\%)\end{array}$ & & & & \\
\hline \multicolumn{7}{|l|}{ Educational status } \\
\hline No education & $285(11.8)$ & $2132(88.2)$ & 1 & \multirow{4}{*}{$\begin{array}{l}1 \\
1.79(1.40-2.29) \\
1.65(1.14-2.39) \\
2.78(1.70-4.54)\end{array}$} & & 1 \\
\hline Primary & $340(29.9)$ & $798(70.1)$ & $2.77(2.21-3.47)$ & & & $1.65(1.27-2.13) *$ \\
\hline Secondary & $150(43.2)$ & $197(56.8)$ & $4.37(3.14-6.08)$ & & & $1.52(1.03-2.24) *$ \\
\hline Higher & $120(67.0)$ & $59(33.0)$ & $12.48(7.95-19.60)$ & & & $2.48(1.45-4.22) *$ \\
\hline \multicolumn{7}{|l|}{ Wealth status } \\
\hline Poorest & $95(6.6)$ & 1337 (93.4) & 1 & \multirow{5}{*}{$\begin{array}{l}1 \\
1.62(1.14-2.32) \\
2.17(1.51-3.11) \\
3.28(2.28-4.71) \\
8.52(5.97-12.17)\end{array}$} & & 1 \\
\hline Poorer & 94 (13.8) & $589(86.2)$ & $2.01(1.41-2.86)$ & & & $1.62(1.12-2.37) *$ \\
\hline Middle & $99(17.5)$ & $468(82.5)$ & $2.93(2.05-4.21)$ & & & $1.82(1.10-3.02) *$ \\
\hline Richer & $126(24.6)$ & $386(75.4)$ & $5.30(3.70-7.59)$ & & & $2.44(1.42-4.21)^{*}$ \\
\hline Richest & $481(54.2)$ & $406(45.8)$ & $21.22(15.18-29.65)$ & & & $4.45(2.43-8.14) *$ \\
\hline \multicolumn{7}{|l|}{ Religion } \\
\hline Muslim & $302(14.8)$ & $1739(85.2)$ & 1 & \multirow{4}{*}{$\begin{array}{l}1 \\
1.80(1.37-2.36) \\
1.04(0.74-1.45) \\
0.91(0.39-2.11)\end{array}$} & & 1 \\
\hline Orthodox & $447(36.5)$ & 779 (63.5) & $3.21(2.34-4.40)$ & & & $1.62(1.22-2.16) *$ \\
\hline Protestant & $135(18.9)$ & $580(81.1)$ & $1.84(1.24-2.71)$ & & & $0.98(0.69-1.38)$ \\
\hline Others & $11(11.1)$ & $88(88.9)$ & $0.99(0.42-2.32)$ & & & $0.89(0.38-2.09)$ \\
\hline \multicolumn{7}{|l|}{ Occupation } \\
\hline No work & $482(19.2)$ & $2028(80.8)$ & 1 & \multirow{5}{*}{$\begin{array}{l}1 \\
1.04(0.77-1.40) \\
1.05(0.79-1.41) \\
0.94(0.61-1.44) \\
0.86(0.48-1.54)\end{array}$} & & 1 \\
\hline Professional & 193 (38.0) & 315 (62.0) & $1.96(1.48-2.61)$ & & & $1.06(0.77-1.45)$ \\
\hline Agricultural & $131(17.8)$ & $605(82.2)$ & $0.87(0.65-1.18)$ & & & $1.08(0.81-1.46)$ \\
\hline Daily labour & $58(27.1)$ & $156(72.9)$ & $1.29(0.84-1.98)$ & & & $0.98(0.62-1.57)$ \\
\hline Others & $31(27.4)$ & $82(72.6)$ & $1.04(0.59-1.82)$ & & & $0.93(0.50-1.75)$ \\
\hline \multicolumn{7}{|c|}{ Age at first birth ( $\mathrm{n}$ years) } \\
\hline$<18$ & $250(17.2)$ & $1200(82.8)$ & 1 & \multirow{3}{*}{$\begin{array}{l}1 \\
1.05(0.84-1.31) \\
1.09(0.75-1.60)\end{array}$} & & 1 \\
\hline $18-24$ & $507(22.3)$ & $1763(77.7)$ & $1.23(0.99-1.53)$ & & & $1.03(0.82-1.30)$ \\
\hline $25+$ & $138(38.2)$ & $223(61.8)$ & $1.83(1.28-2.62)$ & & & $0.90(0.59-1.37)$ \\
\hline \multicolumn{7}{|l|}{ Parity } \\
\hline Primipara & $274(31.1)$ & $607(68.9)$ & 1 & \multirow{3}{*}{$\begin{array}{l}1 \\
1.01(0.78-1.30) \\
1.08(0.76-1.55)\end{array}$} & & 1 \\
\hline Multipara & $492(22.4)$ & $1700(77.6)$ & $0.72(0.57-0.90)$ & & & $1.00(0.77-1.31)$ \\
\hline Grand multipara & $129(12.8)$ & $879(87.2)$ & $0.54(0.40-0.73)$ & & & $1.10(0.75-1.60)$ \\
\hline \multicolumn{7}{|l|}{ Desired child } \\
\hline Wants & $615(21.9)$ & $2188(78.1)$ & 1 & \multirow{3}{*}{$\begin{array}{l}1 \\
0.61(0.37-1.01) \\
1.04(0.82-1.33)\end{array}$} & & 1 \\
\hline Undecided & $34(16.4)$ & 173 (83.6) & $0.62(0.38-1.02)$ & & & $0.59(0.35-1.01)$ \\
\hline Wants no more & $246(23.0)$ & $825(77.0)$ & $0.89(0.71-1.11)$ & & & $1.01(0.78-1.31)$ \\
\hline \multicolumn{7}{|c|}{ Wanted pregnancy when became pregnant } \\
\hline Then & $725(21.9)$ & $2587(78.1)$ & 1 & \multirow{3}{*}{$\begin{array}{l}1 \\
0.99(0.75-1.30) \\
0.66(0.41-1.07)\end{array}$} & & 1 \\
\hline Later & $133(24.4)$ & $412(75.6)$ & $0.98(0.74-1.29)$ & & & $1.03(0.77-1.38)$ \\
\hline No more & $37(16.5)$ & $187(83.4)$ & $0.55(0.34-0.88)$ & & & $0.67(0.39-1.14)$ \\
\hline \multicolumn{7}{|c|}{ Knowledge of prevention method } \\
\hline No & $324(12.8)$ & $2199(87.2)$ & 1 & \multirow{2}{*}{$1.70(1.38-2.10)$} & & 1 \\
\hline Yes & $571(36.6)$ & $987(63.4)$ & $3.29(2.68-4.03)$ & & & $1.66(1.34-2.06) *$ \\
\hline
\end{tabular}


Table 5 Multilevel logistic regression analysis of individual and community-level factors associated with PMTCT option B+ services utilization among women in Ethiopia, EDHS 2016 (Continued)

\begin{tabular}{|c|c|c|c|c|c|c|}
\hline \multirow[t]{2}{*}{ Variables } & \multicolumn{2}{|c|}{ РMTCT option B+ } & \multirow[t]{2}{*}{ COR $(95 \% \mathrm{Cl})$} & \multirow{2}{*}{$\begin{array}{l}\text { Model } 1 \\
\text { AOR }(95 \% \mathrm{Cl})\end{array}$} & \multirow{2}{*}{$\begin{array}{l}\text { Model } 2 \\
\text { AOR }(95 \% \mathrm{Cl})\end{array}$} & \multirow{2}{*}{$\begin{array}{l}\text { Model } 3 \\
\text { (AOR }(95 \% \mathrm{Cl})\end{array}$} \\
\hline & $\begin{array}{l}\text { Utilized } \\
\text { n (\%) }\end{array}$ & $\begin{array}{l}\text { Not utilized } \\
n(\%)\end{array}$ & & & & \\
\hline \multicolumn{7}{|c|}{ Comprehensive knowledge of HIV } \\
\hline No & $500(15.8)$ & $2668(84.2)$ & 1 & \multirow{2}{*}{$\begin{array}{l}1 \\
1.74(1.40-2.17)\end{array}$} & & 1 \\
\hline Yes & $395(43.3)$ & $518(56.7)$ & $3.18(2.55-3.95)$ & & & $1.73(1.38-2.18) *$ \\
\hline \multicolumn{7}{|c|}{ Knowledge on PMTCT } \\
\hline No & $217(11.1)$ & $1732(88.9)$ & 1 & \multirow{2}{*}{$\begin{array}{l}1 \\
2.66(2.14-3.29)\end{array}$} & & 1 \\
\hline Yes & $678(31.8)$ & $1454(68.2)$ & $3.73(3.01-4.63)$ & & & $2.69(2.16-3.36) *$ \\
\hline \multicolumn{7}{|l|}{ Residence } \\
\hline Urban & $430(51.7)$ & $402(48.3)$ & 1 & & 1 & 1 \\
\hline Rural & $465(14.3)$ & $2784(85.7)$ & $0.08(0.06-0.11)$ & & $0.13(0.09-0.19)$ & $0.52(0.32-0.85) *$ \\
\hline \multicolumn{7}{|c|}{ Community wealth status } \\
\hline Poor & $265(11.9)$ & $1970(88.1)$ & 1 & & 1 & 1 \\
\hline Middle & $187(27.0)$ & $505(73.0)$ & $2.29(1.73-3.02)$ & & $2.08(1.57-2.74)$ & $1.25(0.86-1.82)$ \\
\hline Rich & $443(38.4)$ & $711(61.6)$ & $4.49(3.48-5.79)$ & & $3.73(2.89-4.81)$ & $1.38(0.90-2.12)$ \\
\hline \multicolumn{7}{|l|}{ Exposure to media } \\
\hline No & $740(19.3)$ & $3100(80.7)$ & 1 & & 1 & 1 \\
\hline Yes & $155(64.3)$ & $86(35.7)$ & $4.79(3.23-7.11)$ & & $1.72(1.15-2.57)$ & $1.37(0.91-2.06)$ \\
\hline \multicolumn{7}{|c|}{ Women empowerment } \\
\hline Not empowered & $445(17.0)$ & $2181(83.0)$ & 1 & & 1 & 1 \\
\hline Empowered & $401(31.9)$ & $855(68.1)$ & $1.70(1.37-2.13)$ & & $1.17(0.94-1.47)$ & $1.10(0.87-1.38)$ \\
\hline \multicolumn{7}{|c|}{ Distance to the nearest facility } \\
\hline Far & $317(14.4)$ & $1890(85.6)$ & 1 & & 1 & 1 \\
\hline Not far & $578(30.8)$ & $1296(69.2)$ & $1.81(1.44-2.26)$ & & $1.25(0.99-1.57)$ & $1.09(0.86-1.37)$ \\
\hline
\end{tabular}

*statistically significant at $p$-value $<0.05$

AOR Adjusted Odds Ratio, COR Crude Odds Ratio, ICC Intra-class Correlation Coefficient, PMTCT Prevention of Mother-to-Child Transmission, Model 1: adjusted for individual-level characteristics, Model 2: adjusted for community-level characteristics, Model 3: adjusted for both individual and community-level characteristics (full model)

be that as the women got formal education, they can understand the importance of things better and get information from different sources, more fascinated to accept new things and practice new behaviour. So as the mother's educational status (knowledge) increases, their concern for offspring becomes high, so they use the services to reduce its transmission to their child.

Those women in poorer, middle, richer, and richest wealth status were $(1.62,1.82,2.44$, and 4.45$)$ times more likely to utilise the service compared to those in the poorest wealth status. This study was supported by a study conducted in Ethiopia [28] and Amhara region [12, 14]. The possible reason might be they can cover their transportation cost and they can get quality health care services either in private or public health facilities towards their interest. Those orthodox religion followers' women were 1.62 times more utilising PMTCT services than those who follow
Muslim religion; this finding was in line with a study done in Kenya [29].

Those women who had a basic knowledge of HIV prevention methods were 1.66 times more utilised the services compared to their counterparts (AOR: 1.66, 95\% CI: 1.34 2.06). This study was supported by a study done in Addis Ababa and East Hararge [21, 23]. This similarity might be due to having information about the impact of HIV and its preventive method including PMTCT services and health workers might be getting special training on PMTCT service to counsel women. Another significant finding of this study was that women who had knowledge of MTCT of HIV were 2.69 times more utilised the PMTCT services than those who did not know (AOR:2.69, 95\% CI:2.16-3.36). This finding is consistent with a related study done in East Hararge [23] and Amhara region [12, 14].

Furthermore, those rural dwellers were $48 \%$ less likely to utilise the PMTCT services compared to those urban 
dwellers (AOR: 0.52, 95\% CI: 0.32-0.85) and supported by a study done in Ethiopia and Mizan Aman [28, 30]; because those rural dwellers have low information access, physical access centralisation (infrastructure, transportation problem), and women empowerment (poor family support).

\section{Limitation of the study}

The study tried to measure PMTCT services' utilisation during antepartum, intrapartum, and postpartum; however, mothers might experience recall bias, mainly the intrapartum period's services. The other possible bias might be the social desirability bias because the data collectors were health professionals.

\section{Conclusions}

The PMTCT services utilisation in Ethiopia among women during the antepartum, intrapartum, and postpartum periods was surprisingly low and affected by individual and community level factors. The comprehensive knowledge of mothers improves PMTCT utilisation. The utilisation among poor wealth status and rural dweller women was low. Increasing awareness creation on MTCT/PMTCT for women at the community level through strengthening mother group, health development army, as well as HEWs and providing community-based health education on PMTCT services would increase services utilisation in the country. Moreover, the study finding also indicates that the need for better service accessibility, improving the economic status, and empowering HIV-positive pregnant women by raising PMTCT knowledge, especially among uneducated women, will positively affect PMTCT utilisation. Therefore, the federal and regional health bureau and other implementers should emphasise awareness creation and strengthen the existing community-based health extension program to boost PMTCT service utilisation.

\section{Abbreviations}

ANC: Antenatal Care; ART: Antiretroviral therapy; CSA: Central Statistical Agency; EDHS: Ethiopian Demographic Health Survey; MTCT: Mother to child transmission; PMTCT: Prevention of Mother to child transmission of HIV PHC: Primary Health Care; WHO: World Health Organization

\section{Acknowledgments}

We are very thankful to MEASURE DHS for permission to use the EDHS 2016 survey data sets. Moreover, our appreciation also goes to the Institute of Public Health staff, who support us during the preparation of this paper.

\section{Authors' contributions}

TG and TSA conceived the study and analysed the data. AH, BD and NW participated in the data analysis, drafted, edited, and revised the manuscript. All authors read and approved the final manuscript.

\section{Funding}

No funding was secured for this study.

\section{Availability of data and materials}

The data used for the current study will be available upon reasonable requests from the corresponding author.

\section{Declarations}

Ethics approval and consent to participate

The need for ethics approval is unnecessary as it is a secondary analysis of publicly available data. The permission to access the data was obtained from the MEASURE DHS (available from https://www.dhsprogram.com/Data/ and accessed on 07 August 2020) after a brief study concept was submitted.

\section{Consent for publication}

Not applicable.

\section{Competing interests}

All authors declared that they have no competing interest.

\section{Author details}

${ }^{1}$ Department of Health Systems and Policy, Institute of Public Health, College of Medicine and Health Sciences, University of Gondar, Gondar, Ethiopia. ${ }^{2}$ Department of Epidemiology and Biostatistics, Institute of Public Health, College of Medicine and Health Sciences, University of Gondar, Gondar, Ethiopia. ${ }^{3}$ School of Public Health, College of Medicine and Health Science, Wolaita Sodo University, Wolaita Sodo, Ethiopia.

Received: 9 December 2020 Accepted: 4 May 2021

Published online: 03 July 2021

\section{References}

1. HIV/AIDS UJUNPo: Ending the aids epidemic by 2030 aspart of the sustainable development goals. 2016.

2. Organization WH: Ethiopia HIV country profile. 2016 https://www.who.int/ hiv/data/Country_profile Ethiopia.pdf?ua=1

3. UNAIDS. Prevention of HIV transmission from mother to child: strategic options; 1999

4. Frontieres MS. Prevention of mother-to-child transmission (PMTCT) of HIV: protocol; 2017.

5. Kellerman SE, Sugandhi N. Pediatric AIDS in the elimination agenda. PLoS Med. 2013;10(8):e1001503. https://doi.org/10.1371/journal.pmed.1001503.

6. Organization WH: PMTCT strategic vision 2010-2015 : preventing motherto-child transmission of HIV to reach the UNGASS and Millennium Development Goals. 2010

7. UNAIDS. Prevention gap report; 2016.

8. Moges NA, Kassa GM, Boneya DJ. Rate of HIV transmission and associated factors among HIV-exposed infants in selected health facilities of east and west Gojjam zones, Northwest Ethiopia; retrospective cohort study. BMC Infect Dis. 2017;17(1):475. https://doi.org/10.1186/s12879-017-2578-3.

9. Organization WH: Guideline on WHENTO START antiretroviral therapy and on pre-exposure prophylaxis for HIV. 2015

10. UNAIDS JUNPOHA: 2015 Progress report on the golobal plan towards the elimination of new HIV infections among children and keeping their mothers alive. 2015.

11. Kassa GM. Mother-to-child transmission of HIV infection and its associated factors in Ethiopia: a systematic review and meta-analysis. BMC Infect Dis. 2018;18(1):216. https://doi.org/10.1186/s12879-018-3126-5.

12. Akal CG, Afework DT. Status of prevention of mother-to-child transmission (PMTCT) services utilization and factors affecting PMTCT service uptake by pregnant women attending antenatal Care Clinic in Selected Health Facilities of Afar regional state. Ethiopia J Environ Public Health. 2018;2018: 5127090.

13. Deressa W, Seme A, Asefa A, Teshome G, Enqusellassie F. Utilization of PMTCT services and associated factors among pregnant women attending antenatal clinics in Addis Ababa, Ethiopia. BMC Pregnancy Childbirth. 2014; 14(1):328. https://doi.org/10.1186/1471-2393-14-328.

14. Feleke BE, Wasie B. Challenges of PMTCT service utilization in Amhara region: a comparative cross-sectional study. Ethiop J Health Sci. 2018;28(6): 779-86. https://doi.org/10.4314/ejhs.v28i6.13.

15. Worldometer. Ethiopia Demographics of December 10, 2020. https:/www. worldometers.info/demographics/ethiopia-demographics/. 
16. Central Statistical Agency (CSA) [Ethiopia] and ICF. Ethiopia demographic and health survey 2016. Addis Ababa and Rockville: CSA and ICF; 2016. https://dhsprogram.com. In.; 2016

17. Linguissi LSG, Sagna T, Soubeiga ST, Gwom LC, Nkenfou CN, Obiri-Yeboah D, et al. Prevention of mother-to-child transmission (PMTCT) of HIV: a review of the achievements and challenges in Burkina-Faso. HIV/AIDS (Auckland, NZ). 2019:11:165.

18. Hox JJ, Kreft IG. Multilevel analysis methods. Sociological Methods \& Research. 1994;22(3):283-99.

19. Van Duijn MA, Van Busschbach JT, Snijders TA. Multilevel analysis of personal networks as dependent variables. Social Networks. 1999;21(2):187210.

20. Agresti A, Booth JG, Hobert JP, Caffo B. Random-effects modeling of categorical response data. Sociological Methodology. 2000;30(1):27-80.

21. Deressa W. Utilization of PMTCT services and associated factor among pregnant women attending antenatal clinic in Addis Ababa, Ethiopia. BMC Pregnancy Childbirth. 2014;14(1). https://doi.org/10.1186/1471-2393-14-328

22. CSA-Ethiopia I: International: Ethiopia Demographic and Health Survey 2011. Central Statistical Agency of Ethiopia and ICF International Addis Ababa, Ethiopia and Calverton, Maryland, USA 2012.

23. Megersa G, Tariku N, Belay Y, Adeba T, Daniel W, Fufa B, et al. Utilization of Prevention of Mother to Child transmission (PMTCT) services and factors that affect knowledge and service uptake among pregnant women attending antenatal care in East Hararge Zone of Oromia Reginal State. Ethiopian Journal of Health Development. 2014;28(Special Issue):26-35.

24. Fana A, Debela M, Giref AZ, Gebreyesus SH, Yirtaw TG, Bahaga ST, et al. PMTCT service utilization and associated factors among pregnant women attending public health facilities in Hawassa City, southern Ethiopia. Ethiopian J Reprod Health (EJRH). 2019;11:16.

25. Afework2 CGAaDT. Status of prevention of mother-to-child transmission (PMTCT) services utilization and factors affecting PMTCT service uptake by pregnant women attending antenatal Care Clinic in Selected Health Facilities of Afar regional state, Ethiopia. Hindawi J Environ Public Health. 2018:7. https://doi.org/10.1155/2018/5127090.

26. Mustapha M, Musiime V, Bakeera-Kitaka S, Rujumba J, Nabukeera-Barungi N. Utilization of "prevention of mother-tochild transmission" of HIV services by adolescent and young mothers in Mulago hospital, Uganda. BMC Infect Dis. 2018. https://doi.org/10.1186/s12879-018-3480-3.

27. Amare Y, Degefie T, Mulligan B. Newborn care seeking practices in central and southern Ethiopia and implications for community based programming; 2015

28. Elias Asfaw Zegeye, Josue Mbonigaba and Zacharie Tsala Dimbuene: Factors associated with the utilization of antenatal care and prevention of motherto-child HIV transmission services in Ethiopia: applying a count regression mode. https://doi.org/10.1186/s12905-018-0679-9.

29. Ndonga $E$, Matu M. Factors affecting uptake of prevention of mother to child transmission of HIV by women attending antenatal clinic in Pumwani maternity hospital, Nairobi, Kenya. MOJ Public Health. 2019;8(3):90-6.

30. Hailu D, Nigussie W, Gudeta TA, Abdu M, Molla Y, Assefaw G. Assessment of knowledge and attitude towards prevention of mother-to child transmission of HIV/AIDS among antenatal care client in Mizan-Aman town public health facilities, Benchi-Maji Zone, South Nation Nationalities and People Region, Southwest Ethiopia, 2017. Clinics Mother Child Health. 2018; 15(280):2.

\section{Publisher's Note}

Springer Nature remains neutral with regard to jurisdictional claims in published maps and institutional affiliations.

Ready to submit your research? Choose BMC and benefit from:

- fast, convenient online submission

- thorough peer review by experienced researchers in your field

- rapid publication on acceptance

- support for research data, including large and complex data types

- gold Open Access which fosters wider collaboration and increased citations

- maximum visibility for your research: over $100 \mathrm{M}$ website views per year

At BMC, research is always in progress.

Learn more biomedcentral.com/submissions 